\title{
YOUTH'S EXPOSURE AND UTILIZATION OF INTERNET ADVERTISEMENTS IN AWKA, ANAMBRA STATE
}

\author{
Ogonna Anunike, Ph.D \\ Department of Mass Communication \\ Federal Polytechnic, Oko \\ Anambra State Nigeria \\ Phone: +2348134644488 \\ ogoanunike@gmail.com \\ Okechukwu Onuegbu \\ Department of Mass Communication, \\ University of Nigeria, Nsukka \\ Enugu State, Nigeria. \\ $+238061506936$ \\ oonuegbu3@gmail.com
}

\begin{abstract}
This study examined youth's exposure and utilization of internet advertisements, in Awka metropolis, Anambra State. It adopted survey research design. The population of study includes all youth in Awka metropolis. An appropriate sample size of 400 was gotten from the population using probability sampling technique.Six research questions were used as primary data instrument. The finding shows that youths in Awka metropolis were exposed to the Internet advertisements, that majority of youths in Awka metropolis accessed internet advertisements mostly via their android/mobile phones. Also, WhatsApp is the social media platform that youths in Awka metropolis expose themselves to internet advertisements most; that social interaction drives Awka' youth to internet advertisements most, and their exposure to the Internet advertisements influenced them to buy and subscribe to advertised products and services. It is concluded that youths in Awka metropolis are not only exposed to Internet advertisements but also utilize them through buying and subscribing to the advertised products and services daily.
\end{abstract}

Keywords: Awka metropolis, Exposure, Internet, Internet advertisements, Utilization, Youth

\section{INTRODUCTION}

Internet is a medium of mass communication. With it, people can effectively communicate with one another, socialise, and transact businesses and services anytime, even from the comfort of their homes. This view is supported by McCarthy (2007), who posits that the world has been entirely permeated by information and communication technologies which now increasingly determine not only how humans communicate with each other but equally how they live their entire life.

Duru (2014, p. 7) defines Internet as a 'computer-based platform that enables the exchange of information among connected users worldwide', adding that its strength lies in its rich multimedia nature and inexhaustibility as well as the flexibility which it offers the user.

Agba (2001) further reiterates that uniqueness of internet is that it brings far greater information empowerment to humans. It could be because the Internet has continued to gro 
in popularity since its invention owing to availability of numerous technological devices used in accessing it such as desktop computers, laptop computers, mobile phones, palmtops, and etc. Baran (2010) observes that Internet has become the most influential communicative force globally. His reason could be because the Internet helps people to live and relate effectively with their environments as well as to achieve economic, political, scientific and cultural aspirations.

According to Obiajulu (2008), access to the Internet is an essential variable in measuring social empowerment, enhancing one's active participation and self-assertion in the social milieu. Thus, Duru (2011) contends that sharing of texts, pictures, sounds, videos and graphics are parts of activities performed on the Internet.

This boils down to internet advertising or internet advertisements because they were placed on the Internet by identified persons with the aim of getting people to search and use them. Advertising is one prominent activity often carried out on the web with the primary purpose of attracting consumers (users) to buy products; goods and services. Thus, Nwodu (2017), while stressing that every media technology or content has a unique purpose it serves, describes advertising as a professional practice that involves the production of the commercial messages.

Statista (2018), an online United Kingdom weekly internet users reviewer adds e-mail, banking, communications, transactions, social media networking, news dissemination, watching of video clips and internet televisions, health, listening to internet radio/ audio services, government services, games upload and adding of content as forms of internet advertisements. There is no doubt that these various internet innovations gave rise to many internet or electronic terminologies like electronic mails (email), internet advertising, electronic books (e-Book), electronic journals (e-journals), to mention a few.

Adeleke (2016) further categorizes these internet advertising agents and products they market. The companies that deal on general merchandise or marketers of all kinds of goods and services are Jumia Nigeria, Konga, Dealdey, Yudala, Payports, Veonnet among others. Companies that deal on fashion and wears are Fashpa and Tracklist. The Glooing and others market groceries and food. Mall for Africa and others undertake delivery and logistics. The Dlx, Jijiing and others work for marketplaces. Also private property and property 24 companies are in real estate. Those in furniture are showrooming and furnishing. Sloting deals on electronics; Cheki Nigeria on automobile; while Wukan among others deal on travel. But there are also other internet platforms renowned for news dissemination, sports betting (Bet9ja, Nairabet), entertainment, etc.

Perhaps, this is why Deshwal (2016) posits that the rapid technological development and rise of Internet, new media and communication channels tremendously changed the advertisement business landscape. It has made it possible for people to largely depend on it (Internet) as the ultimate source of advertisements, information and communication. He gave types of online advertising as floating ads, expanding ads, wallpaper ads, trick banner ads, pop-up ads, popunder ads.Others are, video advertising, advertising on social networks, mobile advertising, email advertising, banner advertising, Google search advertising and a lot more.

McCoy, Galletta, Everard, Polak (2004) detailed some of the effects of these types of internet advertisements when they insisted that pop-up, pop-under, and in-line ads have essential effects on user perception and cognition. It could be why Li $(2002$, p. 2) posits "online 
consumers are goal-oriented and perceive advertisements to be even more intrusive when viewed in other media".

Among the world retinue of internet users are the youths, whom the United Nations (UN) classify as persons between the ages of 15 and 24; 18 to 35 by the 1999 Constitution of Federal Republic of Nigeria (as amended) (the 1999 Second National Youth Policy Document of Federal Republic of Nigeria, p. 6,). Salako and Tiamiyu (2007) see the young generation (youth) as the most prominent users of these internet advertising and other information.

Okoye (2014, p. 18) supports this position, "The Internet is a relatively young invention and naturally the young who are usually adventurous and enthusiastic are jumping into it. The possible reason is having access to and being trained on the Internet is a gateway to such empowerment given that the Internet is at the heart of communications today".

Also, Duru (2014) argues that students constitute an important segment of these young internet users and potential users since they are being trained to succeed within an information-based society. Hence, training on Internet is naturally indispensable to their success in this endeavor. Goldsmith and Lafferty (2002), while studying students' use of internet advertisements noted that consumer (students) response to ads on web sites and their influences on them are impressive.

Chaubey, Sharma and Pant (2013) claim that internet advertisements motivate consumers to patronize goods and services. Also, that most companies and industries prefer to use it for advertising their products rather than use other media platforms like radio, televisions, and newspapers. Their reason is that internet advertising is less expensive in terms of money, time and other resources usually expended on it, wider geographical reach, easy result measurement, more targeted audiences, speed, informative, smooth audience engagement and product branding.

\section{Objectives of the study}

The study was guided by the following objectives:

Find the rate Awka youths exposed themselves to internet advertisements.

$>$ Find out the various devices through which youths in Awka metropolis access internet advertizements.

$>$ Find out the social media platforms through which youths in Awka metropolis expose themselves to Internet advertizements.

$>$ Determine the need gratifications that drive youths in Awka metropolis to expose themselves to internet advertisements.

$>$ Find out the extent to which youths in Awka metropolis utilize internet advertisements.

Find out if the utilization is as a result of their exposure to the Internet.

\section{THEORETICAL UNDERPINNING}

This study applied Uses and Gratification and Technological Determinism theories. Both theories are to cover any lapses either of them could have while exploring youth's exposure and utilization of internet advertisements. 


\section{Uses and Gratification Theory (UGT)}

Uses and Gratification theory is an approach to understanding why and how people actively seek out specific media content to satisfy particular needs. Onuegbu (2016) describes it as an audience-centered approach to understanding mass communication. It was propounded in the 1940's, when researchers became interested in why people engaged in various forms of media behaviour, such as radio listening or newspaper reading. These early studies were primarily descriptive, seeking to classify the responses of audience members into meaningful categories.

Uses and Gratification theory was used in this research because researchers, who use the approach theory, assume that audience members are aware of the impact of the media, and can articulate their reasons for consuming various media content. Herzog (1944) identified three types of gratification associated with listening to radio soap operas to include emotional release, wishful thinking, and obtaining advice.

According to McQuail (1983), this theory suggests that audience attitude toward media behaviour is an essential factor in media use, adding that original conception of its approach is based on the research for explaining the great appeal of specific media contents. In the mass communication process, uses and gratifications approach puts the function of linking need gratifications and media choice clearly on the side of audience members. That is, the Uses and Gratification theory is concerned with audience response to media contents such as advertising, news, etc. in the society) and tension free needs (use of the media as a means of escapism and to relief from tension).

However, Levy and Windahl (1984) add that there are many antecedent variables such as media structure, media technology, social circumstances, psychological variables, needs, values, and beliefs that all relate to the particular gratification pattern used by the audience. On his part, Swanson (1987) suggested that researchers should focus on (1) the role of gratification seeking in exposure to mass media, (2) the relationship between satisfaction and the interpretive frames through which audiences understand media content, and (3) the link between pleasure and media content.

\section{Technological Determinism Theory (TDT)}

Technological Determinism theory believes that growing technologies shape man's feelings, actions and thoughts. It was propounded by Marshal McLuhan in 1962, who believed that human beings act, learn, feel and think the way they do as a result of the messages they receive through the current technologies as the society moves from one technological age to another. Historically, these technologies started with the print (books, newspapers, magazines, etc.) to the radio, television, and currently, the Internet. That is, the current society believes, feels, learn and act in consonance with what they gather from these modern technological advancements. They were developed by humans, controlled by humans; yet they control humans. Thus Culkin (1967) says that users shape these tools, and they in turn shape the users

Webster (2017) says though there are different accounts of technological determinism, a view often associated with it is the technological imperative which involves rhetoric and underlying assumptions. He opions that technology has a controlling influence that is inevitable and unstoppable. It was further bolstered by Canole $(2007$,$) who claimed that the$ introduction of new technologies has transformed the society. 
Webster (2017) opines that educational technology leaders have an ideological orientation to technical change, and believed that it has an absolute autonomy and in charge in the society. Webster concludes that technological determinist assumptions and the technical imperative such as normative and unintended consequences were alive, well and significant in people's thinking. However, Goguen (2000,) while studying the social aspects of technology and science, said technological determinism is an autonomous force that changes society.

These theories are relevant to this study in that Uses and Gratification plays out in the advertisements while Internet is a major technology that drives all aspect of global business and undertakings.

\section{REVIEW OF RELATED EMPIRICAL STUDIES}

Over the years, some researchers all over the world focused on youth exposure and utilization of internet advertisements. This section reviews three works of these researchers and their findings.

Padon, et. al.(2018)investigated Alcohol brand use of youth appealing advertising. The researchers further tested the association between the youth-appeal of marketing content of televised alcohol advertisements and the brand-specific alcohol consumption of both underage youth and adults.

The finding shows that brand CAY scores were (a) positively associated with brand-specific youth consumption after controlling for adult brand consumption; (b) positively associated with a ratio of youth-to adult brand-specific consumption, and; (c) not associated with adult brand consumption. It therefore, concludes that alcohol brands with youth-appealing advertising are consumed more often by youth than adults.

Gupta, et.al. (2017) studied the association between exposure to social media alcohol marketing and youth alcohol use behaviours in India and Australia. The study objective was to discover if young people aged 13 and 25 are exposed to, interact with social networking sites-based alcohol marketing and their level of alcohol consumption (use).

It discovered that India and Australia have different alcohol consumption features due to variations in socio-cultural norms. In India, it found that $35 \%$ of youths consume $1 / 3$ of alcoholic drinks every day due to online alcohol advertisements they are exposed, whereas $45 \%$ of youths in Australia do the same thing. The teenagers drinking habits increase in both countries as a result of their exposure to alcohol advertisements on Internet.

Bakare, Owusu, and Abdurrahaman, (2017) researched on the behaviour response of the Nigerian youths toward mobile advertising: An examination of the influence of values, attitudes and culture. The findings are that the youths are exposed to internet advertisements and also utilize them for their behaviors diverse needs.

The above literature shows that people expose themselves to internet advertisements and utilize them. However, information on Awka resident youths on the subject is not known. Therefore, this work seeks to examine the rate Awka youth expose themselves to and use internet advertisements.

\section{METHOD}

The research design for this study is descriptive research. Akubilo (2003, p. 58) says that descriptive analysis collects data when the issue involved is related to opinion, attitude 
Volume 1 Number 2

beliefs and behaviours. The researchers chose the questionnaire as the instrument of measurement. It is appropriate for this study because it seeks to study 'Youth exposure and utilization of Internet advertisements' in Awka metropolis.

Awka, the capital of Anambra State, is the area of the study. A sample size of 400 was selected and the researcher's adopted probability sampling. Instrument for data collection was the questionnaire used to answer the research questions. The questionnaire was divided into two, section A and section $\mathrm{B}$. The section A seeks to elicit information regarding the respondents' bio-data, and the B section asked questions bordering on the research questions and objectives.

Thus, these researchers adopted structured or a close- ended questionnaire. It was chosen because it is a data collection tool mostly suited for descriptive surveys like this. This research instrument adopted was validated by three experts in communication.

\section{RESULTS}

The method of data analysis used in this research was frequency tables and simple percentages. A total of four hundred (400) copies of the questionnaire was administered and returned.

Table 1: Respondents Demographic Characteristics

\begin{tabular}{|l|l|l|}
\hline $\begin{array}{l}\text { Response/category } \\
\text { Gender }\end{array}$ & Frequency & Percentages (\%) \\
\hline Male & 213 & $53 \%$ \\
\hline Female & 187 & $47 \%$ \\
\hline Total & 400 & $100 \%$ \\
\hline Age & & \\
\hline $18-20$ years & 79 & $20 \%$ \\
\hline $21-25$ years & 94 & $23 \%$ \\
\hline $26-30$ years & 99 & $25 \%$ \\
\hline $31-35$ years & 128 & $32 \%$ \\
\hline Total & 400 & $100 \%$ \\
\hline Education & & \\
\hline O/L and FSLC & 161 & $40 \%$ \\
\hline OND/NCE & 102 & $26 \%$ \\
\hline HND/BSc & 123 & $31 \%$ \\
\hline MSC/PhD & 14 & $3 \%$ \\
\hline Total & 400 & $100 \%$ \\
\hline Marital Statues & & \\
\hline Single & 221 & $55 \%$ \\
\hline Married & 131 & $26 \%$ \\
\hline Divorced & 25 & $31 \%$ \\
\hline Widow/widower & 23 & $6 \%$ \\
\hline Total & 400 & $100 \%$ \\
\hline & &
\end{tabular}

Table 1 on the demographic characteristics of the respondents show that $53 \%(n=213)$ of them were male while $47 \%(n=187)$ were female. Male respondents were more than female respondents because males seemed to have more interest in internet business. 
Volume 1 Number 2

The age characteristics of the respondents indicates that about $20 \%$ of them $(n=79)$ were between the ages of $18-20$ years. Those whose age bracket ranged from 21-25 years were about 23\% ( $\mathrm{n}=94)$; the age bracket between $26-30$ years were about $25 \%(\mathrm{n}=99)$ while the age bracket between $31-35$ were about $32 \%(n=128)$. The age brackets $31-35$ were more in number.

Educational attainment of the respondents shows that majority of them were ordinary level / First school leaving certificate holders and HND/BA/BSC holders $(n=161$ or $40 \%$, and $n=123$ or $31 \%$ respectively). However, OND/NCE holders account for $31 \%(n=123)$, while MSc and $\mathrm{PhD}$ holders were about $3 \%(\mathrm{n}=14)$.

Marital status of the respondents shows that $55 \%(n=221)$ of them were single, $33 \%(n=131)$ were married, $6 \%(n=15$ and $n=23)$ were divorced and widow/widowers respectively. The singles were the majority because they seem to be more among the youth.

Occupational distribution of the respondents shows that majority of them were students and public servants ( $\mathrm{n}=163$ or $41 \%$ and 151 or $37 \%$ respectively). However, business men / women accounted for $23 \%(n=83)$ while artisans/technicians constitute $1 \%(n=3)$

Table 2: Respondents Exposure to Internet

\begin{tabular}{|l|l|l|}
\hline Exposure to Internet & Frequency & Percentages (\%) \\
\hline Once a day & 144 & $36 \%$ \\
\hline About three times a day & 73 & $18 \%$ \\
\hline Once in a week & 166 & $42 \%$ \\
\hline I do not expose myself at all & 17 & $4 \%$ \\
\hline Total & 400 & $100 \%$ \\
\hline
\end{tabular}

Data in table 2 indicate that 144 respondents representing $36 \%$ expose themselves to Internet once every day; 73 (18\%) respondents are exposed to it about three times every day, 166 $(42 \%)$ respondents are exposed to internet once every week, while $17(4 \%)$ respondents did not expose themselves to the internet. As a result, 383 respondents who are exposed to internet were used subsequently for the study.

Table 3: Respondents' Exposure to Internet Advertisements

\begin{tabular}{|l|l|l|}
\hline $\begin{array}{c}\text { Exposure to internet } \\
\text { advertisement }\end{array}$ & Frequency & Percentages (\%) \\
\hline Once in a day & 120 & $32 \%$ \\
\hline About three times a day & 105 & $27 \%$ \\
\hline Once a week & 151 & $39 \%$ \\
\hline I do not expose myself at all & 7 & $2 \%$ \\
\hline Total & 383 & $100 \%$ \\
\hline
\end{tabular}

In the table 3 above, out of 383 respondents that expose themselves to internet advertisements, 120 representing $31 \%$ exposed themselves to internet advertisements every day; $105(27 \%)$ expose themselves to internet advertisements about three times a day. Also, $151(39 \%)$ expose themselves to the internet advertisements once every week; while $7(2 \%)$ did not expose themselves to internet advertisements. People who were expose one in a week were in the majority.

Table 4: Devices Respondents use in accessing Internet Advertisements 
Volume 1 Number 2

\begin{tabular}{|l|l|l|}
\hline $\begin{array}{l}\text { The device often used in } \\
\text { accessing } \\
\text { advertisements }\end{array}$ & Frequency & Percentages (\%) \\
\hline Laptop & 83 & $22 \%$ \\
\hline Android/mobile phone & 136 & $36 \%$ \\
\hline Palmtop & 70 & $19 \%$ \\
\hline Desktop computers & 87 & $23 \%$ \\
\hline Total & 376 & $100 \%$ \\
\hline
\end{tabular}

Table 4 above indicates that out of 376 respondents who exposed themselves to internet advertisements.About 83 respondents representing 22\% used laptop computers in accessing advertisements on the internet; $136(36 \%)$ used android/mobile phones. Also 70 (19\%) respondents used palmtop; while 87 (23\%) used desktop computers to access the internet for advertisements. Respondents who used android/mobile phone to access the advertisement are in the majority.

Table 5: Types of Internet advertisements respondents were exposed to

\begin{tabular}{|l|l|l|}
\hline $\begin{array}{l}\text { Type of Internet } \\
\text { advertisement exposed to }\end{array}$ & Frequency & Percentages (\%) \\
\hline Audio/Visual & 92 & $24 \%$ \\
\hline Texts & 99 & $26 \%$ \\
\hline Pictures/Images & 98 & $26 \%$ \\
\hline Graphics animations/cartoons & 87 & $24 \%$ \\
\hline Total & 376 & $100 \%$ \\
\hline
\end{tabular}

In the table 5 above, out of 376 respondents that participated in the study, 92 representing $24 \%$ were either exposed to audio or video advertisements on Internet; 99 (26\%) respondents are expose to texts advertisement on Internet; 98 (26\%) respondents were expose to internet pictures and images advertisements; while $87(24 \%)$ respondents were expose to internet graphics and cartoons advertisements. Respondents who were exposed to texts and pictures/images tied together.

Table 6: Internet Platforms Respondents were exposed to advertisements

\begin{tabular}{|l|l|l|}
\hline Internet platforms I mostly view Advertisements & Frequency & Percentages (\%) \\
\hline Facebook & 66 & $18 \%$ \\
\hline YouTube & 58 & $15 \%$ \\
\hline Twitter & 53 & $14 \%$ \\
\hline Instagram & 29 & $8 \%$ \\
\hline WhatsApp & 102 & $27 \%$ \\
\hline Websites & 31 & $8 \%$ \\
\hline Blogs & 37 & $10 \%$ \\
\hline Total & 376 & $100 \%$ \\
\hline
\end{tabular}

Data in table 6 above indicate the internet platforms youths in Awka metropolis expose themselves to advertisements most. They are as follow; Facebook had a record of 66 respondents representing 18\%, YouTube 58 (15\%) respondents, Twitter 53 (14\%) respondents, Instagram 29 (8\%) respondents, WhatsApp $102(27 \%)$ respondents, Websites 31 
Volume 1 Number 2

(8\%) respondents, and blogs $37(10 \%)$ respondents. The respondents used Whatsapp platform more than any other platform.

Table 7: Reasons Youth in Awka Metropolis access Internet Advertisements

\begin{tabular}{|l|l|l|}
\hline $\begin{array}{l}\text { Reasons to access internet } \\
\text { advertisements }\end{array}$ & Frequency & Percentages (\%) \\
\hline Information & 81 & $22 \%$ \\
\hline Education & 98 & $26 \%$ \\
\hline Entertainment & 87 & $23 \%$ \\
\hline Social interaction & 110 & $29 \%$ \\
\hline Total & 376 & $100 \%$ \\
\hline
\end{tabular}

Data in the table 7 above, reveal that out of 376 respondents (100\%)that participated in the study, 81 representing 22\% access internet advertisements for information, 98 (26\%) respondents access it for education; 87 (23\%) respondents for entertainment, and 110 (29\%) respondents access it for social interaction. Respondents for social interaction are in the majority.

Table 8: Youth in Awka Metropolis Utilisation of Internet Advertisements

\begin{tabular}{|l|c|c|}
\hline $\begin{array}{l}\text { Utilization of internet } \\
\text { advertisements for }\end{array}$ & Frequency & Percentages (\%) \\
\hline $\begin{array}{l}\text { To know of new products in } \\
\text { the markets }\end{array}$ & 91 & $24 \%$ \\
\hline $\begin{array}{l}\text { To know how to use some } \\
\text { products }\end{array}$ & 97 & $26 \%$ \\
\hline To buy some products & 96 & $24 \%$ \\
\hline $\begin{array}{l}\text { To share some products or } \\
\text { ideas with family and friends }\end{array}$ & 92 & $100 \%$ \\
\hline Total & 376 & \\
\hline
\end{tabular}

Data in table 8 above showed 91 (24\%) of respondents utilize internet advertisements to ascertain new products in the markets. It helps 97 (26\%) of respondents to understand how to use some products; helps 96 (26\%) of respondents to buy some products. Also, it helps 92 (24\%) of respondents to share some products/marketing ideas with family and friends.

Table 9: Internet Advertisements Influence and Utilization of Advertised Products

\begin{tabular}{|l|l|l|}
\hline $\begin{array}{l}\text { Internet advertisements and } \\
\text { utilization of internet } \\
\text { advertised products }\end{array}$ & Frequency & \\
\hline $\begin{array}{l}\text { Attracting me to buy or } \\
\text { venture into a trade or } \\
\text { services }\end{array}$ & $27 \%$ \\
\hline $\begin{array}{l}\text { Increased my rate of buying } \\
\text { or subscribing to } \\
\text { products/services }\end{array}$ & 118 & $31 \%$ \\
\hline $\begin{array}{l}\text { Decreased my rate of buying } \\
\text { or subscribing to products or } \\
\text { services }\end{array}$ & 48 & $13 \%$ \\
\hline Made me an expert or addict & 109 & $29 \%$ \\
\hline
\end{tabular}


Volume 1 Number 2

to products or services

\begin{tabular}{|l|l|}
\hline Total & 376 \\
\hline
\end{tabular}

$100 \%$

Data in table 9 above indicate how advertised products on the internet influenced the respondents' rate of utilization of advertised products. About 101 (27\%) were attracted to buy or venture into a trade or services. Also 118 (31\%) respondents had their buying and subscribing to products or services increased. It decrease the rate of buying or subscribing to products or services of $48(13 \%)$ respondents; and it made $109(29 \%)$ respondent experts or addicted to products and services.

\section{DISCUSSIONS}

The findings of this study revealed that many respondents exposed themselves to internet advertisements. Thus 120 (30\%) exposed themselves to it once in a day; $105(27 \%)$ respondents about three times a day and 151 (39\%) respondents once in a week. The outcome is in line with Erinn, Onuiri and Omoniyi (2016) whose descriptive survey research on Attitude of Social Media Users to Internet Advertising shows youth's exposure in the majority. Also Holmberg (2011) in observational and explorative study discovered Children's exposure to online advertising.

On the devices used by the youth to access internet advertising $83(22 \%)$ respondents used laptop, $136(36 \%)$ respondents used android/mobile phone, $70(19 \%)$ respondents used palmtop and $87(23 \%)$ respondents used desktop computers. It indicates that youths in Awka metropolis used android/mobile phones most in accessing the internet advertisements. It corroborates the findings of Edegoh, Anunike and Nwagbara (2015) whose survey research work, Patterns of online media exposure among young people in Anambra State shows that majority of the respondents accessed the web through cell phone/handset.

On the social media platforms the youths were exposed to internet advertisements. The finding indicate that WhatsApp has 102 (27\%) respondents; Facebook, 66 (18\%) respondents; Youtube, $58(15 \%)$ respondents among others.Findings from the study is that WhattsApp group chats took the lead.It differs from Gupta, Lam, Pettigrew and Tait (2018) whose cross-sectional (online survey) revealed that, association between exposure to social media alcohol marketing and youth alcohol use behaviours in India and Australia uncovered that the internet platforms where youths expose themselves to advertisements mostly are on YouTube. Similarly, in Asa (2013), Children and advertising on social media websites, conducted in the United Kingdom, 90\% of respondents reported exposure to advertisements on Facebook. The reasons for the dissimilarities are locations and time of research. This study was conducted in Nigeria in 2018; the others were done in Australia and United Kingdom in 2018 and 2013 respectively.

Another finding of this study showed that the main gratification that made Awka Youths to expose themselves to the internet advertisements was social interaction. The need for information has 81 (22\%) respondents, education has 98 (26\%); entertainment has 87 (23\%) respondents and social interaction 110 (29\%) respondents. It supports $\mathrm{Wu}$ and $\mathrm{Li}(2017)$ in a study of effects of mass media exposure and social network site involvement on risk perception of and precautionary behaviour toward the Haze issue in China. They discovered that youths exposed themselves to online platforms and advertisements to communicate with other users (social interaction) more than any other need. 
Volume 1 Number 2

Also, another finding of this study in Table 8 is that Awka residents utilize internet advertisements mostly for direction on how to use the product. This finding is in line with Musa (2016) whose survey research, "How Kano State residents utilize Internet advertisements" discovered that the majority use internet advertisements to discover new and existing products in the market; this is followed by those that were taught how to use some products.

Another findings is the internet advertisements influenced youths in Awka metropolisby attracting them to buy or venture into trade or services (101 respondents representing 27\%); This agrees with the finding of Acharya, Khanal,Singh, Adhikari, and Gautam (2015), who discovered that the more the youths are aware of something, the more they patronise or get involved in it.

\section{CONCLUSION}

The study therefore, concludes that Awka Youths are not only exposed to internet advertisements but also utilized them through buying and subscribing to the products and services advertised.

\section{REFERENCES}

Acharya, D. (2015). Impact of mass media on the utilization of antenatal care services among women of rural community in Nepal. Retrived February, 20, 2018 from https://www.ncbi.nlm.nih.gov/pmc/articles/PMC4534014/

ACTDA (2018). History of Awka Capital Territory. Retrived March 5, 2018, from http://fromactda.com.ng/history-of-Awka-capital-territory/

Adeleke, D. (2016). The 20 most popular Nigerian eCommerce sites. Accessed on March 5, 2018, on https://techpoint.ng/2016/07/01/20-popular-nigerian-ecommerce-sites/

Agba, P.C. (2001). Electronic reporting heart of the new communication age. Nsukka: University of Nigeria Press.

Asa (2013). Children and advertising on social media websites. Accessed on September 30, 2018, from https://www.asa.org.uk/asset/FA34B8D3-2E1B-4A14892FCECFD09938EB/

Bakare, A. S., Owusu, A. \& Abdurrahaman, D. T. (2017). The behaviour response of the Nigerian youths toward mobile advertising: An examination of the influence of values, attitudes and culture. Cogent Business \& Management Journal, 1(1). Accessed on February 12, 2018 from https://www.tandfonline.com/doi/full/10.1080/23311975.2017.1353231

Baran, B. (2010). Facebook as formal instructional environment. British: Journal of Educational Technology. 1 (6): 188.

Canole, G. (2007): Designing for learning in an open world. In Canole G. (ed), The role of Mediating Artefacts in learning Design. Available http//www.cloudworks.ac.uk/cloud/view/5410. 
Volume 1 Number 2

Caroll, S. R. (2018). Instrument Reliability. Accessed June 5, 2018, from http://www.dissertationstatistics.com/instrument-reliability.html

Chaubey, D. S., Sharma, L. S.,\& Pant, M. (2013). Measuring the Effectiveness of Online Advertisement in Recalling a Product: An Empirical Study. Internet research, (4), 2. $\begin{array}{lllll}\text { Accessed on } & \text { March } & \text { 5, from }\end{array}$ https://www.inflibnet.ac.in/ojs/index.php/MC/article/viewFile/31 $127 / 2442$.

Deshwal, P. (2016). Online Advertising and its impact on consumer behaviour. New-Delhi: International Journal of Applied Research, 2 (2).

Duru, H. C. (2011). Expanding the Learning Environment Through the Internet:

Towards a More Dynamic Curriculum for Communication Education in Nigeria. A paper presented at Prof. Nwuneli International Conference held at Awka, Anambra State, July 4 and 5, 2011.

Duru, H. C. (2014). Teachers' awareness and response to the risk of students' reliance on the Internet for academic work: A study of secondary school teachers in Onitsha South Local Government Area of Anambra State. Unpublished PGDE research project submitted to National Teachers Institute, Kaduna.

Edegoh, L. O., Anunike, O. W.,\& Nwagbara, G. U. (2015). Patterns of online media exposure among young people in Anambra State, Nigeria. New Media and Communication, 43.

Erinn, C., Onuiri, E.,\& Omoniyi, I. (2016). Attitude of Social Media Users to Internet Advertising. Journal of Applied Science, International Journal of Research \& Development Organisation. 2 (1). Accessed February 25, 2018, on https://www.researchgate.net/publication/305426624_Attitude_of_Social_Media_Use rs_to_Internet_Advertising

Eze, D. (2018). Nigeria's population hits 198 million people-NPC Chairman. Accessed June 1, 2018, on http://population.gov.ng/nigerias-population-hit-198m-people-npopcchairman/

Goguen, J (2000). Social aspect of technology and science. Accessed June 4, 2018, on https://cseweb.ucsd.edu/ goguen/courses/275f00/s3.html\#narrative

Goldsmith, Ronald \& Lafferty, Barbara. (2002). Consumer response to Web sites and their influence on advertising effectiveness. Internet Research. 12. 318-328. 10.1108/10662240210438407.

Gupta, H., et. al (2017). The association between exposure to social media alcohol marketing and youth alcohol use behaviours in India and Australia. Accessed April 6, 2018, on https://link.springer.com/content/pdf/10.1186\%2Fs 12889-018-5645-9.pdf

Herzog, H. (1944). What do we really know about daytime serial listeners? In P.F. Lazarsfeld (ed.), Radio research 1942-3 (pp. 2-23). London: Sage. 
INEC (2017). INEC voters's situation reports. Abuja: 2017 Anambra governorship election.

Kuskis, A (2013). We shape our tools and thereafter our tools shape us-McLuhan. Available on https://www.google.com/amp/s/mcluhangalaxy.wordpress.com/2013/04/01/weshape-our-tools-and-thereafter-our-tools-shape-us/amp/

Levy, M., \& Windahl, S. (1984). Audience activity and gratifications. US Communication Research, 11 (3).

Li, Hairong, Edwards, Steven M., and Lee, Joo-Huyn (2002) "Measuring the intrusiveness of advertisements: Scale development and validation," Journal of Advertising, 31(2), 37 47.

McCoy, Scott; Everard, Andrea; Galletta, Dennis; and Polak, Peter (2004). "A Study of the Effects of Online Advertising: A Focus on Pop-Up and In-Line Ads" (2004). SIGHCI 2004 Proceedings.

McQuail, D. (1983). Mass communication theory. London: Sage.

Ojekunle, O. (2016). Factors influencing home ownership among civil servants in Ibadan metropolis. Hamburg: Anchor Academic publishing.

Okoye, J. S. (2011). "Impact of the Social Media on the Academic Endeavours of Undergraduates in Lagos State." A Masters Thesis submitted to the Department of Mass Communication, University of Lagos.

Onuegbu, O. C. (2016). The Impact of ABS Radio News on Listeners. Unpublished degree project submitted to Department of Mass Communication, National Open University of Nigeria, Lagos.

Padon, A. A.,. (2018). Alcohol brand use of youth-appealing advertising and consumption by youth and adults. Accessed on June 12, 2018, on https://www.ncbi.nlm.nih.gov/pmc/articles/PMC5941256/

Pew Internet \& American Life Project Tracking Surveys (2017). Nearly half of Americans use digital voice assistants, mostly on their smartphones. Accessed on July 6, 2018 on http://www.pewresearch.org/fact-tank/2017/12/01/first-time-internet-users-who-theyare-and-what-they-do-when-they-get-online/

Pew Internet \& American Life Project Tracking Surveys (2017). A survey of American Internet users. Accessed on July 6, 2018 on http://www.pewinternet.org/

Salako, O. \& Tiamiyu, Mutawakilu. (2007). Use of search engines for research by postgraduate students of the University of Ibadan, Nigeria. African Journal of Library, Archives and Information Science. 17. 103-115. 
Volume 1 Number 2

Statista.com (2017). Online activity categories carried out in the prior week in the United

Kingdom (UK) in 2017.Accessed on April 2, 2018 on https://www.statista.com/statistics/2

71793/online-activities-carried-out-in-the-prior-week-in-the-united-kingdom/

Statista.com (2018). Internet Users in Nigeria. Accessed on June 2, 2018 on https://www.statista .com/statistics/183849/internet-users-nigeria/

Swanson, D. L. (1987). Gratification seeking, media exposure, and audience interpretations. Journal of Broadcasting and Electronic Media, 31(3).

Webster, J. G. \& Taneja, H. (2017). Media Exposure Measurement. Accessed on April 16, 2018, On http://www.oxfordbibliographies.com/view/document/obo9780199756841/obo-9780199756841-0164.xml.

$\mathrm{Wu}, \mathrm{X}$ and Li, X (2017). Effects of Mass Media Exposure and Social Network Site Involvement on Risk Perception of and Precautionary Behavior Toward the Haze Issue in China. International Journal of Communication 11, 3975-3997.

Youth Policy (1999). The Second National Youth Policy Document of Federal Republic of Nigeria, 1 (1). 